\title{
University student perceptions of water resource issues and management in the Pacific Northwest, USA
}

\author{
R. L. Mahler ${ }^{1} \&$ M. E. Barber ${ }^{2}$ \\ ${ }^{I}$ Soil Science Division, University of Idaho, USA \\ ${ }^{2}$ Department of Civil and Environmental Engineering, \\ University of Utah, USA
}

\begin{abstract}
The purpose of this paper is to document university student perceptions of the status of water resources in the Pacific Northwest. Water resource perceptions of 7,400 students at the University of Idaho (Moscow, ID, USA) were measured between 1993 and 2014. As part of a learning assessment study students in the large freshman environmental science class were asked several questions about the environment in a standardized survey on both the first and last day of class. In this way changes in student perceptions as a result of the course could be quantified. This survey included several questions about water resources, including water quantity, water quality and drinking water. For each statement in the survey students were asked to choose one of the following answers: (1) strongly agree, (2) agree, (3) no opinion, (4) disagree, or (5) strongly disagree. Key findings of this study include: (1) most students initially believed that water pollution had increased in the last 25 years; however, after the class they believed that water pollution had decreased; (2) students did not consider water shortages a serious problem in the region; (3) student views changed from not emphasizing to emphasizing the need for water conservation in homes and yards; (4) over threequarters of students that took this class believe that water from the tap in cities was safe to drink; and (5) students changed their views on bottled water - a majority disagree that bottled water is safer than tap water. Student major, gender, and year surveyed (1994 vs. 2014) also had an impact on student answers.

Keywords: public opinion, college student attitudes, water quality, water quantity, drinking water.
\end{abstract}




\section{Introduction}

The public considers water resources (both quality and quantity) to be the most important environmental issue in the four Pacific Northwest states - Alaska, Idaho, Oregon and Washington [1-4]. These four states heavily utilize this resource for agriculture $(6,000,000$ irrigated ha), commerce, power production, direct human water consumption, food processing and recreation. Starting at a young age children are exposed to environmental education in schools. Consequently, most citizens understand the importance of this resource. Students entering college bring with them a set of mores about water issues that have been strongly influenced by schools, peers and relatives.

\section{Background}

Most students entering college in the USA bring with them a set of values that have been influenced by their parents, high school peers and community members. Many of these values are beliefs that are not strongly rooted in science. Consequently, most universities require students to take one or more science classes regardless of their career choice. This requirement is based on the need for students to be familiar with the scientific method so that they can understand science-based issues. A general course in environmental science is often used to meet this need.

Because of this need an introductory course in environmental science was developed in 1993 at the University of Idaho. In addition to the need to enhance the science literacy of non-science majors this course was designed to teach students about environmental issues from a science perspective based on the scientific method, rather than being based on the bias of advocacy. In this way students could base their actions toward issues on science rather than bias or simple beliefs. The 18 environmental issues covered in this course included: (1) population growth, (2) food resources, (3) ecology, (4) biodiversity, (5) nonrenewable energy sources, (6) renewable energy sources, (7) water quality, (8) water quantity, (9) drinking water, (10) atmospheric air pollution, (11) indoor air pollution, (12) acid deposition, (13) ozone depletion, (14) climate change, (15) solid waste disposal, (16) sewage disposal, (17) hazardous waste, and (18) emerging issues.

The vast majority of students enrolled in this large lecture class were not science majors. In fact this is the only college level science class taken by over $40 \%$ of the enrolled students. The teaching methodology used to evaluate this class included a traditional evaluation of the class completed by the student and a second instrument that is covered in this paper. This second instrument consisted of 32 to 52 statements about environmental issues that students were asked to strongly agree, agree, disagree, strongly disagree or have no opinion about. This instrument was given to students on the first day of class (week 1) and again during the last week of the term (week 15) so that student opinion change could be measured. The change in student opinion allowed the instructor (senior author) and the 
Environmental Science Program at the University of Idaho to assess learning outcomes and to measure student opinions about environmental issues.

The purpose of this paper is to measure student opinions about the water resource questions that were part of this assessment instrument. Consequently, questions relating to water quality, water quantity and drinking water are evaluated in this paper.

\section{Methodology}

A survey instrument containing between 30 and 52 statements (semester dependent) about specific environmental issues was developed in 1993. This instrument contained seven statements about water quality, water quantity and drinking water. The specific statements about water quality were:

"In the USA water pollution has become worse over the last 25 years"

"I consider water in local rivers and lakes clean enough for swimming"

The specific statements about water quantity were:

"Water shortages in the Pacific Northwest are a serious problem"

"Water conservation should be emphasized in homes and yards"

The specific statements about drinking water were:

"In cities water from the tap is safe to drink"

"For drinking purposes bottled water is safer than tap water"

"Pesticides are a common contaminant in drinking water"

For each of the 30 to 52 statements the students were instructed to circle one of the following answers: SA (strongly agree), A (agree), N (neutral or no opinion), $\mathrm{D}$ (disagree), or strongly disagree (SD). This survey instrument was included in the syllabus packet that students received on the first day of class. In addition to the survey answers students provided information about their major, gender and year in college. Students turned in the completed survey questionnaire on their way out of the classroom. Students again received the same survey during the fifteenth week of the semester. Again the completed survey instrument was collected at the end of the class period.

The same survey procedure was repeated for 45 straight semesters from fall 1993 through fall 2014. During this period of time 7,485 students completed the two surveys. The average number of completed surveys was 166 per semester. Because of the way the study was conducted it was estimated that the student response rate exceeded $94 \%$.

The data from each completed survey were summarized and a statistical analysis was performed to measure opinion change [5-8]. The collective 45 semester data sets were analyzed using SAS and where appropriate, t-tests and orthogonal contrast comparisons were used to evaluate the interactions of gender, survey year, student major and year in college.

\section{Results and discussion}

The seven survey questions discussed in this paper were asked of students who took Environmental Science 101 every semester from fall term 1993 through fall 
term 2014. This class was taught every semester during this period for a total of 45 times. Enrolment ranged from a low of 27 in fall 1993, the first time this class was taught, to a peak of 367 in spring 2010. Students took this class for one of the three following reasons: (1) general interest, (2) requirement for their major, or (3) to fulfil the university science requirement required of all students. During this 23year period 7,485 students answered the seven survey questions contained in this paper during the first (before) and fifteenth (after) weeks of the semester.

\subsection{Water quality}

The summary answers to the statements "In the USA water pollution has become worse over the last 25 years" and "I consider water in local rivers and lakes clean enough for swimming" are shown in Table 1 . When averaged over the 23-year study, $50.2 \%$ of the students came into the class believing that lakes and rivers in the region were clean enough for swimming. By the end of the class the percentage of students considering local water bodies safe enough for swimming increased to $56.6 \%$. Even though this change was statistically significant this class did not impact the initial view by the majority of students. Student views about the safety of regional rivers and lakes for swimming are in large part supported by available scientific data.

Table 1: University of Idaho student reactions to the water quality statements "In the USA water pollution has become worse over the last 25 years" and "I consider water in local rivers and lakes clean enough for swimming”. $(\mathrm{N}=7,463 ; \mathrm{p}=0.00001$. $)$

\begin{tabular}{|c|c|c|c|}
\hline Statement & Response & Before (week 1) & After (week 15) \\
\hline
\end{tabular}

In the USA water pollution has become worse over the last 25 years.

$\begin{array}{lll}\text { Strongly agree/agree } & 60.4 & 20.2 \\ \text { Strongly disagree/disagree } & 12.4 & 61.2 \\ \text { Neutral } & 27.2 & 18.6\end{array}$

I consider water in local rivers and lakes clean enough for swimming.

$\begin{array}{lll}\text { Strongly agree/agree } & 50.2 & 56.6 \\ \text { Strongly disagree/disagree } & 30.5 & 28.4 \\ \text { Neutral } & 19.3 & 15.0\end{array}$

Student perceptions about water pollution in the USA were impacted by the course as $60.4 \%$ of students initially agreed that water pollution in the USA had become significantly worse in the last 25 years $(\mathrm{p}=0.00001)$. However, by the end of the course only $20.2 \%$ of students thought that water pollution had become 
worse. In fact a majority of students $(61.2 \%)$ disagreed with the initial survey statement by the time the term ended (Table 1). Both gender (Table 2) and student major (Table 3) impacted how students viewed long-term water pollution trends in the region.

Table 2: The influence of gender on University of Idaho students agreeing (strongly agree + agree) with the water quality statement "In the USA water pollution has become worse over the last 25 years". ( $n=7,449$; $\mathrm{p}=0.00001$.)

\begin{tabular}{lcc}
\hline Gender & Before (week 1) & After (week 15) \\
\hline & ---18.8 \\
Male & 46.6 & 18.8 \\
Female & 74.2 & 21.4 \\
All respondents & 60.4 & 20.2 \\
\end{tabular}

Table 3: The influence of major on University of Idaho students agreeing (strongly agree + agree) with the water quality statement "In the USA water pollution has become worse over the last 25 years". $(n=7,412$; $\mathrm{p}=0.00001$.)

\begin{tabular}{lcc}
\hline Major & Before (week 1) & After (week 15) \\
\hline & 55.4 & 15.4 \\
Agriculture & 70.1 & 19.2 \\
Architecture & 50.3 & 10.5 \\
Business & 76.2 & 28.3 \\
Education & 48.4 & 16.0 \\
Engineering & 50.5 & 14.2 \\
Forestry & 74.2 & 25.3 \\
General Studies & 80.2 & 29.1 \\
Humanities & 55.5 & 14.5 \\
Science & 75.3 & 26.8 \\
Social Science & 60.4 & 20.2 \\
All respondents & & \\
\hline
\end{tabular}

Female students were much more likely than males (74.2\% vs. $46.6 \%)$ to agree that surface water pollution had become worse in the last 25 years (Table 2) $(p=0.00001)$. However, by the end of the course only about one quarter of both females and males felt that surface water quality had deteriorated. The gender gap about water pollution was large at the beginning of the class but almost disappeared by week 15 .

Student major had a significant impact on student perceptions about surface water pollution trends (Table 3$)(\mathrm{p}=0.00001)$. At the beginning of the class a 
majority of students in all majors except engineering agreed with the statement that water pollution had become worse over the last 25 years (Table 1). However, by week 15 less than $30 \%$ of students in all majors agreed that water quality had deteriorated. Students majoring in architecture, education general studies, humanities and social sciences were more likely to view water pollution as increasing both at the start (week 1) and end of this class (week 15). Conversely, students majoring in business, engineering and forestry were least likely to indicate that water pollution was getting worse.

\subsection{Water quantity}

The summary to the statements "Water shortages in the Pacific Northwest are a serious problem" and "Water conservation should be emphasized in homes and yards" are shown in Table 4. When averaged over the 23 -year study, only $10.2 \%$ of the students came into the class believing that water shortages in the Pacific Northwest were a serious problem. By the end of the class (week 15) the percentage of students considering water shortages a serious problem increased to $14.6 \%$. Although this difference is significant $(\mathrm{p}=0.02)$ a large majority of students still do not believe that water shortages are an important regional issue. A larger change was observed with the water conservation statement as only $20.2 \%$ of students believed that water conservation should be emphasized in homes and yards during week 1 in the class, but this percentage increased to $52.3 \%$ by week 15 (Table 4). Both gender (Table 5) and survey year (Table 6) impacted how students viewed the importance of water conservation in homes and yards.

Table 4: University of Idaho student reactions to the water quantity statements "Water shortages in the Pacific Northwest are a serious problem" and "Water conservation should be emphasized in homes and yards". $(\mathrm{n}=7,447 ; \mathrm{p}=0.00001$.)

\begin{tabular}{|c|c|c|c|}
\hline Statement & Response & Before (week 1) & After (week 15) \\
\hline
\end{tabular}

Water shortages in the Pacific Northwest are a serious problem

$\begin{array}{lll}\text { Strongly agree/agree } & 10.2 & 14.6 \\ \text { Strongly disagree/disagree } & 74.3 & 65.9 \\ \text { Neutral } & 15.5 & 19.5\end{array}$

Water conservation should be emphasized in homes and yards

$\begin{array}{lll}\text { Strongly agree/agree } & 20.2 & 52.3 \\ \text { Strongly disagree/disagree } & 40.3 & 30.1 \\ \text { Neutral } & 39.5 & 17.6\end{array}$


Table 5: The influence of gender on University of Idaho students agreeing (strongly agree + agree) with the water quantity statement "Water conservation should be emphasized in homes and yards". ( $n=7,435$; $\mathrm{p}=0.00001$.)

\begin{tabular}{|c|c|c|}
\hline Gender & Before (week 1) & After (week 15) \\
\hline & \multicolumn{2}{|c|}{ |--------------------- \% 0 ---------------------- } \\
\hline Male & 14.5 & 37.1 \\
\hline Female & 26.4 & 67.2 \\
\hline All respondents & 20.2 & 52.3 \\
\hline
\end{tabular}

Table 6: The influence of survey year on University of Idaho students agreeing (strongly agree + agree) with the water quantity statement "Water conservation should be emphasized in homes and yards". (n=7,479; $\mathrm{p}=0.00001$.)

\begin{tabular}{lcc}
\hline Survey years & Before (week 1) & After (week 1) \\
\hline & 16.8 & 42.0 \\
$1993-1994$ & 16.4 & 45.2 \\
$1995-1999$ & 20.2 & 46.0 \\
$2000-2004$ & 23.1 & 58.3 \\
$2005-2009$ & 25.6 & 64.1 \\
$2010-2014$ & 20.2 & 52.3 \\
All years & & \\
\hline
\end{tabular}

At the beginning of the course (week 1) female students were more likely than males $(26.4 \%$ vs. $14.5 \%)$ to agree that water conservation should be emphasized in homes and yards (Table 5) $(\mathrm{p}=0.0002)$. This gender difference continued and was observed again at week $15(\mathrm{p}=0.00001)$. Females were almost twice as likely as males to agree that home and yard water conservation should be emphasized. Female agreement with the emphasis on home and yard water conservation increased from one quarter of respondents during week one to over two-thirds of respondents at week 15 .

Survey year also had a significant impact on student perceptions about water conservation in homes and yards (Table 6) $(\mathrm{p}=00001)$. The viewed importance of water conservation in homes and yards increased over time in both the initial survey (week 1) and the conclusion of the course (week 15). Less than $20 \%$ of students starting the course (week 1) in 1993-1999 considered home water conservation important. However, by 2005 over $23 \%$ of entering students agreed with the importance of water conservation in the home $(\mathrm{p}=0.03)$. This same trend was observed in week 15 as students citing home water conservation as being important increased from $42 \%$ in $1993-1994$ to $64.1 \%$ in 2010-2014 surveys. 


\subsection{Drinking water}

The summary to the drinking water statements "In cities drinking water from the tap is safe to drink," "For drinking purposes bottled water is safer than tap water," and "Pesticides are a common contaminant in drinking water" are shown in Table 7. When averaged over the 23 -year study, $56.2 \%$ of the students came into the class believing that water coming from the tap in cities is safe to drink. By the end of the class (week 15) the percentage of students considering tap water safe to drink increased to $78.2 \%$. This increase can largely be attributed to classroom education about the Safe Drinking Water Act passed by Congress in 1973. Both gender (Table 8) and student major (Table 9) impacted how students viewed the safety of drinking water from the tap.

Table 7: University of Idaho student reactions to the drinking water statements "In cities drinking water from the tap is safe to drink", "For drinking purposes bottled water is safer than tap water", and "Pesticides are a common contaminant in drinking water". $(n=7,481 ; p=0.00001$.)

\begin{tabular}{|c|c|c|c|}
\hline Statement & Response & Before (week 1) & After (week 15) \\
\hline
\end{tabular}

In cities drinking water from the tap is safe to drink

$\begin{array}{lrr}\text { Strongly agree/agree } & 56.2 & 78.2 \\ \text { Strongly disagree/disagree } & 36.5 & 15.3 \\ \text { Neutral } & 7.3 & 6.5\end{array}$

For drinking purposes bottled water is safer than tap water

$\begin{array}{lll}\text { Strongly agree/agree } & 64.2 & 16.1 \\ \text { Strongly disagree/disagree } & 10.3 & 53.8 \\ \text { Neutral } & 25.5 & 30.1\end{array}$

Pesticides are a common contaminant in drinking water

$\begin{array}{llr}\text { Strongly agree/agree } & 21.3 & 4.2 \\ \text { Strongly disagree/disagree } & 50.8 & 80.2 \\ \text { Neutral } & 27.9 & 15.6\end{array}$

Male students were more likely than females $(61.5 \%$ vs. $50.9 \%)$ to agree that in cities water from the tap is safe to drink (Table 8) $(\mathrm{p}=0.004)$. By the end of the class (week 15) there was no gender gap $(p=0.61)$ and over three-quarters of students agreed that tap water in cities was safe to drink. 
Student major had a significant impact on student perceptions about the safety of drinking water from taps in the city (Table 9) $(\mathrm{p}=0.0004)$. At the beginning of the class a majority of students majoring in engineering, forestry, architecture and agriculture agreed with the statement that it was safe to drink the water from taps in cities. Conversely, only a minority of students majoring in education, general studies, humanities and social science considered city tap water safe to drink (Table 9). By class week 15 a majority of students in all majors considered city tap water safe to drink.

Table 8: The influence of gender on University of Idaho students agreeing (strongly agree + agree) with the drinking water statement "In cities drinking water from the tap is safe to drink". $(n=7,438 ; p=0.00001$.)

\begin{tabular}{lcc}
\hline Gender & Before (week 1) & After (week 15) \\
\hline & ---1.5 & 78.8 \\
Male & 50.9 & 77.5 \\
Female & 56.2 & 78.2 \\
All respondents & & \\
\hline
\end{tabular}

Table 9: The influence of major on University of Idaho students agreeing (strongly agree + agree) with the drinking water statement "In cities drinking water from the tap is safe to drink". $(n=7,427 ; p=0.00001$.)

\begin{tabular}{lcc}
\hline Major & Before (week 1) & After (week 15) \\
\hline & ---1 & 83.4 \\
Agriculture & 60.1 & 78.2 \\
Architecture & 58.2 & 80.0 \\
Business & 63.6 & 73.2 \\
Education & 41.7 & 88.1 \\
Engineering & 67.0 & 76.8 \\
Forestry & 59.2 & 70.4 \\
General Studies & 48.2 & 69.1 \\
Humanities & 43.8 & 85.5 \\
Science & 63.8 & 74.1 \\
Social Science & 46.1 & 78.2 \\
All respondents & 56.2 & \\
\hline
\end{tabular}

During the first week of the term $64.2 \%$ of students agreed with the statement for drinking water purposes bottled water is safer than tap water in cities. The positive response to this statement fell to only $16.1 \%$ in week 15 (Table 7). This decrease in support for this statement can again be attributed to education in the classroom. Lectures covering the Clean Water Act of 1972, the Safe Drinking Water Act of 1973, recent information about federal regulations related to both tap 
and bottled water, and information about published studies were used to compare both drinking water sources [9-13]. Both gender (Table 10) and survey year (Table 11) impacted how students viewed the safety of bottled water compared to tap water.

Table 10: The influence of gender on University of Idaho students agreeing (strongly agree + agree) with the drinking water statement "For drinking purposes bottled water is safer than tap water". $(n=7,452$; $\mathrm{p}=0.00001$.)

\begin{tabular}{lcc}
\hline Gender & Before (week 1) & After (week 15) \\
\hline & ---------- & \% \\
Male & 52.3 & 14.8 \\
Female & 75.9 & 17.5 \\
All respondents & 64.2 & 16.1
\end{tabular}

Table 11: The influence of survey year on University of Idaho students agreeing (strongly agree + agree) with the drinking water quantity statement "For drinking purposes bottled water is safer than tap water". $(n=7,466$; $\mathrm{p}=0.00001$.)

\begin{tabular}{lcr}
\hline Survey years & Before (week 1) & After (week 1) \\
\hline & - 1 -o- & \% \\
$1993-1994$ & 73.5 & 20.5 \\
$1995-1999$ & 66.4 & 18.8 \\
$2000-2004$ & 60.2 & 18.9 \\
$2005-2009$ & 58.2 & 14.0 \\
$2010-2014$ & 60.1 & 8.1 \\
All years & 64.2 & 16.1 \\
\end{tabular}

Female students were much more likely than males (75.9\% vs. 52.3\%) to agree that bottled water was safer for drinking than tap water at the beginning of the course (Table 10) $(\mathrm{p}=0.00001)$. By week 15 less than $20 \%$ of both female and male students considered bottled water safer than tap water. Slightly more females than males felt that bottled water was safer than tap water at this stage of the course $(\mathrm{p}=0.02)$.

Survey year also had a significant impact on student perceptions about the safety of bottled vs. tap water for drinking purposes (Table 11). Students surveyed at the beginning of the class between 1993 and 1999 were more likely to consider bottled water safer than tap water than students in the first week of class between 2000 and 2014. This same trend was apparent in week 15 although far fewer students considered bottled water safer than tap water. 
More than $20 \%$ of students entering this class supported the statement that pesticides are a common contaminant in drinking water in week 1 (Table 7); however, by the end of the class less than $5 \%$ of students agreed with this statement. Again, education about drinking water, its distribution and Federal standards were believed responsible for this change in student thinking. Impacts of gender, major and survey year did not affect student opinions about the presence of pesticides in drinking water.

\section{Conclusions and recommendations}

Students attending the University of Idaho came into the introductory environmental science class with strong opinions about water quality, water quantity and drinking water issues. Many times their initial opinions contradicted the existing scientific evidence. However, when presented with scientific information student opinions often changed by the completion of their introductory course. Examples of this change were noted for water quantity, water quality and drinking water issues. Student gender, major and the year surveyed often impacted a student's view. Key findings of this study include:

- A majority of students initially believed that water pollution had increased in the last 25 years; however, by the end of the course most students believed that water pollution was decreasing

- A majority of students believe that surface waters in the Pacific Northwest are safe for swimming

- Students do not consider water shortages a serious problem in the Pacific Northwest

- $\quad$ Student views changed over the 15-week course from not emphasizing to emphasizing the need for water conservation in homes and yards

- $\quad$ Over three-quarters of students that took this class believe that water from the tap in cities is safe to drink

- $\quad$ Students changed their views on bottled water; by the end of the class a majority disagreed that bottled water was safer than tap water

- $\quad$ Fewer than $5 \%$ of students consider the presence of pesticides in drinking water a problem

This long-term study (23 years) of student views about important water issues is the most comprehensive study of its kind. This study will be continued for the next several years. In addition to documenting how environmental education can impact student views the data provided in this study also shows how society views have changed over time. For instance 15 to 20 years ago bottled water was considered an excellent commodity because it was a source of safe drinking water. However, in recent years the cost of bottled water and the associated waste (plastic bottles) have put this commodity in a less positive light. An additional important finding of this study is that through education at the college level students learn the right information from which they can make scientifically sound decisions about water issues. This course and similar courses at other universities do prepare students for making sound decisions in an increasingly complex world. 


\section{Acknowledgement}

The authors would like to acknowledge the 7,400+ undergraduate students at the University of Idaho who took part in this survey process.

\section{References}

[1] Mahler, R. L., Simmons, R., Sorensen, F., \& Miner, J.R., Priority water issues in the Pacific Northwest, Journal of Extension (Online), 42(5). Article 5RIB3. Available at: http://www.joe.org/joe/2004october/rb3.php, 2004.

[2] Mahler, R.L., Gamroth, M., Pearson, P., Sorenson, F., Barber, M.E. \& Simmons, R., Information sources, learning opportunities and priority water issues in the Pacific Northwest, Journal of Extension (Online), 48(2). Article 2RIB2. Available at: http://www.joe.org/joe/2010april/rb2.php, 2010.

[3] Dunlap, R.E., Trends in public opinion toward environmental issues: 19651990. Society \& Natural Resources, 4, pp. 285-312, 1991.

[4] Mahler, R. L., Simmons, R., \& Sorensen, F., Drinking water issues in the Pacific Northwest. Journal of Extension, 43(6): 6RIB6, online at: http://www.joe.org/joe/2005december/rb6.php, 2005.

[5] Salent, P., \& Dillman, D., How to Conduct your own Survey. John Wiley and Sons, Inc. New York, New York, 1994.

[6] Dillman, D., Mail and Internet Surveys: The Tailored Design Method. John Wiley and Sons, Inc. New York, New York, 2000.

[7] SAS Institute Inc., SAS Online Document 9.1.3. Cary, North Carolina: SAS Institute Inc., 2004.

[8] Babbie, E., The practice of social research. 3rd edition. Wadsworth Publishing Company. Belmont, CA. pp. 359, 424, 1983.

[9] Doria, M., Bottled water versus tap water: understanding consumerspreferences. Journal of Water Health, pp. 271-276, 2006.

[10] $\mathrm{Hu}, \mathrm{Z}$., Morton, L. W., \& Mahler, R. L., Bottled water: United States consumers and their perceptions of water quality. International Journal of Environmental Research and Public Health, 8, pp. 565-578, 2011.

[11] Levallois, P., Grondin, J. \& Gingras, S., Evaluation of consumer attitudes on taste and tap water alternatives in Quebec. Water Science and Technology, 40(6), pp. 135-139, 1999.

[12] Faure, M. G., The EC directive on drinking water: institutional aspects, 87 pages, Springer, Netherlands, 1994.

[13] Biswas, Asit K. Water management for major urban centres. Water Resources Development, 22(2), pp. 183-197, 2006. 